\title{
Cancer subtypes classification using long non-coding RNA
}

\author{
Ronan Flippot ${ }^{1, *}$, Gabriel G. Malouf ${ }^{1, *}$, Xiaoping Su ${ }^{2}$, Roger Mouawad ${ }^{1}$, Jean-Philippe \\ Spano ${ }^{1}$ and David Khayat ${ }^{1}$ \\ ${ }^{1}$ Groupe Hospitalier Pitié-Salpêtrière, Department of Medical Oncology, University Pierre and Marie Curie (Paris VI), Institut \\ Universitaire de Cancérologie, AP-HP, Paris, France \\ 2 Department of Bioinformatics and Computational Biology, University of Texas MD Anderson Cancer Center, Houston, TX, \\ USA \\ * The authors have contributed equally as co-first authors \\ Correspondence to: Gabriel G. Malouf, email: gabriel.malouf@aphp.fr \\ Keywords: long non-coding RNAs, IncRNAs, cancer, classification, prognosis \\ Received: November 08, $2015 \quad$ Accepted: May 30, $2016 \quad$ Published: June 21, 2016
}

\section{ABSTRACT}

Inter-tumor heterogeneity might explain divergent clinical evolution of cancers bearing similar pathological features. In the last decade, genomic has highly improved tumor subtypes classification through the identification of oncogenic or tumor suppressor drivers. In addition, epigenetics and long non-coding RNAs (IncRNAs) are emerging as new fields for investigation, which might also account for tumor heterogeneity. There is growing evidence that modifications of IncRNA expression profiles are involved in cancer progression through epigenetic regulation, activation of pro-oncogenic pathways and crosstalks with other RNA subtypes. Consequently, the study of IncRNA expression profile will be a key factor in the future for charting cancer subtype classifications as well as defining prognostic and progression biomarkers. Herein we discuss the interest of IncRNA as potent prognostic and predictive biomarkers, and provide a glimpse on the impact of emerging cancer subtypes classification based on IncRNAs.

\section{INTRODUCTION}

The attempts to classify cancer subtypes answer the need for better patients' management. Indeed, the identification of different prognostic groups, predictive factors of response to therapy, or specific oncogenic mechanisms help the clinician to better monitor patients, to personalize treatments at an individual scale, and to avoid the harm caused by a useless regimen. These classifications were historically based on clinical, pathological, and laboratory markers. Among them, the IMDC (international metastatic renal cell carcinoma database) prognostic classification for renal cell carcinoma, based on clinical and laboratory markers, defines the prognosis and therapeutic options for patients in the first-line setting [1]; the pathological subtyping of breast cancer identifies the patients that will mostly benefit from endocrine or anti-HER2 therapy [2]; the identification of deficient mismatch repair in colon cancer categorizes a subset of patients that will less likely benefit from adjuvant chemotherapy [3].
In the last decade, predictive markers of tumor recurrence have benefited from the increasing accessibility of molecular biology and the arrival of next-generation sequencing technologies, that allow for more accurate depiction of genomic and epigenetic alterations in cancer. In breast cancer, the transcriptomic profiling of 50 genes has identified four distinct subtypes of breast cancer with specific ontogeny [4], and a recurrence score based on the expression of 21 genes has been validated to determine the patients who will benefit from adjuvant treatment [5]. Another example is the $\mathrm{CpG}$ island methylator phenotype (CIMP), initially discovered in colon cancer that has since been reported to be associated with $I D H 1$ and IDH2 mutations in glioblastoma [6] and associated with improved prognosis. The latter association is explained by epigenetic reprogramming mediated by $I D H 1$ and $I D H 2$ alterations [7] which are putative targets of experimental treatments [8]. Thus, it is impressive to see that molecular medicine has entered clinical practice and led to a better tumor subtype characterization, with new emphasis on the interplay between genetic and epigenetic aberrations in 
solid tumors, and new developments in targeted therapies.

However, despite these advances, many questions remain unsolved. Indeed, primary resistance to targeted therapies might occur despite of the presence of a targetable alteration: response rates reach a ceiling at $65 \%$ in $B R A F$-mutated melanoma treated by $B R A F$ inhibitors [9], and $71 \%$ in EGFR-mutated lung cancer [10]. In addition, similar genetic alterations in different cancers are not always associated with identical outcomes [11]. These differences indicate that other mechanisms account for tumor progression and resistance to treatments, among which non-coding genome might be strongly involved.

Functional non-coding genome encompass DNA sequences that do not lead to protein coding products, which include ribosomal RNAs, transfer RNAs, micro RNAs, piwi-interacting RNAs and long non-coding RNAs [12]. Among them, long non-coding RNAs (lncRNAs) are key regulators of cellular processes, and are currently emerging as drivers for tumor aggressiveness and patients' outcome [13]. Herein we will provide insights of their oncogenic properties, discuss the interest of new classifications involving lncRNAs expression in clinical practice and introduce their contribution for optimal patient management.

\section{OVERVIEW OF LONG NON-CODING RNA LANDSCAPE}

LncRNAs are eukaryotic RNAs $>200$ nucleotides that do not have protein-coding capacity. Their expression is distinct from protein-coding genes and depends on the tissue and cellular context [14]. Most lncRNAs are intergenic or antisense transcripts that share transcription similarities with messenger RNAs. For instance, they lack an extended open reading frame and their transcription is dependent on the RNA polymerase II and are under the control of the transcriptional activators of the SWI/SNF complex. Finally, most of of the transcripts are capped and polyadenylated [15]. LncRNAs can be present in each cell compartment, where they interact with proteins and chromatin thanks to secondary structures such as stem loops and hairpins, acquired through post-transcriptional modifications. These secondary structures allow them to perform various functions. LncRNAs can act as scaffolds to bring protein complexes together, can guide proteins such as transcription factors to their DNA targets, bend chromatin to act as transcriptional enhancers, or act as decoys to wash out proteins from chromatin (Figure 1) [16]. These functions allow lncRNAs to have a crucial role on various cellular processes [17].

LncRNA comprehension has been greatly enhanced by whole human genome analyses that provided a comprehensive dataset of human lncRNAs, detailing their expression, function, and distribution in the human genome (Figure 2) [18]. Still, the classification of lncRNAs remains to be unified, as they can be sorted according to various features: their structure, their sequence, their function, their metabolism, and their interaction with protein-coding genes or other known DNA elements [19].

Recent studies have highlighted the implication of lncRNAs in cancer progression, mainly through epigenetic regulation, activation of oncogenic pathways and crosstalks with other RNA subtypes [20,19]. Consequently, lncRNAs seem to be natural candidates as novel cancer biomarkers.

\section{ONCOGENIC PROCESSES ASSOCIATED WITH LNCRNA ALTERATIONS}

\section{Epigenetic modifications}

LncRNAs are able to interact with chromatin remodeling complexes, leading to modifications in the expression of target genes in cis, on the vicinity of the IncRNA sequence, or in trans, at independent loci throughout the genome [21]. HOTAIR was one of the first oncogenic lncRNA reported to be involved in cancer progression through genome-wide epigenetic reprogramming $[22,23,24]$, through the interaction with polycomb repressive complex 2 (PRC2) subunits, a key chromatin remodeling complex involved in gene
A

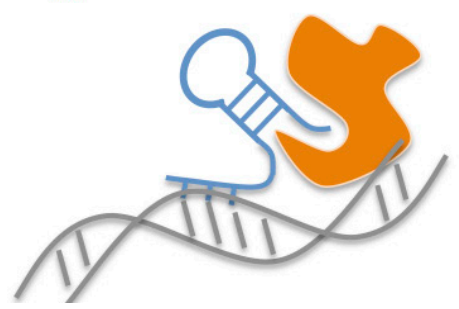

B

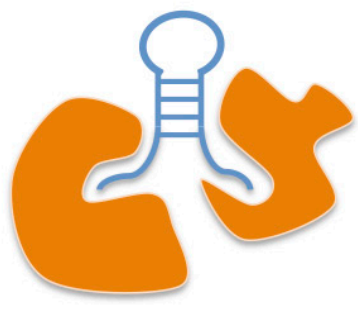

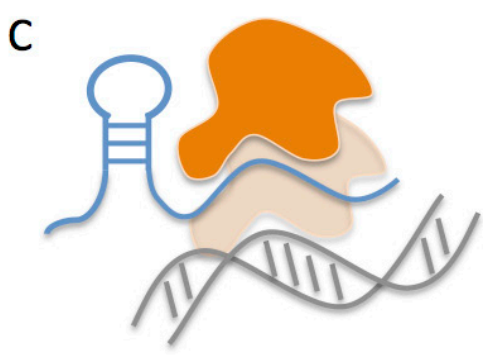

Figure 1: Main mechanisms of action of IncRNAs. Adapted from Rinn et al. [16]. A. LncRNAs can guide proteins to DNA sequences, such as chromatin remodeling proteins. B. LncRNAs can act as scaffolds to induce the formation of functional protein complexes. C. LncRNAs can mimic DNA structures and act as decoys for proteins with DNA binding activity. 
silencing [25]. In a cancer setting, HOTAIR recruits PRC2 subunits in promoter regions of tumor suppressor genes, which leads to their transcriptional repression and favours tumor progression. Accordingly, numerous lncRNAs are involved in regional or genome wide chromatin state regulation, such as MALAT-1 or ANRIL, among the most frequently expressed lncRNA in tumors [26, 27].

\section{Oncogenic signaling pathways}

LncRNAs have a crucial role in the activation of oncogenic signaling pathways that drive the cancer phenotype [28]. The oncoproteins MYC and p53, frequently deregulated in cancers, are under the influence of lncRNA regulations. MYC gene alterations consist mostly in amplifications, as a result of copy gains of 8p24. It has been reported by Tseng et al [29] that IncRNA PVT1 is needed for MYC dependent oncogenesis. PVT1 is indeed localized in the same locus, and coamplified with MYC in $98 \%$ of MYC amplified tumors. Other lncRNAs are involved in the regulation of $M Y C$ expression, such as lncRNA XLOC_010588, downregulated in bladder cancer [30]. Conversely, transcriptional activation of oncogenic IncRNAs are directly mediated by MYC, such as CCAT1 in colon cancer [31] and H19 in gastric cancer [32]. Regarding p53, it has been reported to be regulated by numerous non-coding RNAs [33]. Notably, lincRNA-p21, a downstream target of $\mathrm{p} 53$, links to ribonucleoprotein hnRNP-k to induce global p53 target gene repression and inhibition of apoptosis in lung cancer models [34]. MALAT-1 is also reported to inhibit $p 53$ gene expression and its target genes in various tumors [33]. In contrast, other $\operatorname{lncRNAs}$ increase apoptosis and are thus thought to be tumor suppressors, notably GAS5 in prostate cancer [35] and breast cancer cell-lines [36].

Among key oncogenic drivers, PI3K/MTOR/AKT and MAP kinases pathways are frequently promoted by
lncRNAs alterations. ANRIL in gastric cancer represses miRNAs directed against mTOR [37]. LncRNA RMEL3 in necessary for the activation of BRAF and AKT in melanoma cell lines [38]. LncRNA PTENpg1 represses PTEN expression by recruiting DNMT3A and EZH2 to PTEN promoter region [39]. In contrast, PTENP1 acts as a decoy for regulators miRNAs that leads to increased PTEN function [40]. Similarly, KRAS1P also acts as a decoy for negative regulators of KRAS, thus enhancing KRAS function [40]. Other deregulations in proliferation pathways include the NFKB pathway, activated by BANCR in gastric cancer [41], and the lipid signaling molecules sphingosine kinases, activated by HULC in hepatocellular carcinoma [42].

Some lncRNAs are strongly associated with epithelial-mesenchymal transition (EMT) and cell migration. LncRNA-ATB in hepatocellular carcinoma [43] and MALAT-1 in bladder cancer [44] are positive regulators of TGF- $\beta$ signaling, a key pathway for of EMT. Oncogenic lncRNAs GAPLINC in gastric cancer [45] and MVIH in non small cell lung cancer [46] upregulate CD44 and MMP2/9, proteins involved in cell migration. HOTAIR up-regulation is also associated with EMT, inducing downregulation of E-cadherin and high expression of Vimentin and Metalloproteinase 9 (MMP9) in colon cancer [47]. Conversely, BANCR acts as an antioncogene in non small cell lung cancer [48], as it impairs cell invasion through upregulation of E-cadherin, and downregulation of Vimentin and N-cadherin.

Other pathways notably regulated by lncRNAs include hormone signaling, cell cycle progression, or reactivation of development genes. In prostate cancer, NEAT1 [49] and PRNCR1 [50] are key elements of estrogen and androgen signaling, respectively. LncRNAs MIR31HG [51] and ANRIL are associated with cell cycle progression through the regulation of cyclin-dependent kinases inhibitors [52]. LncRNAs such as HOTTIP in

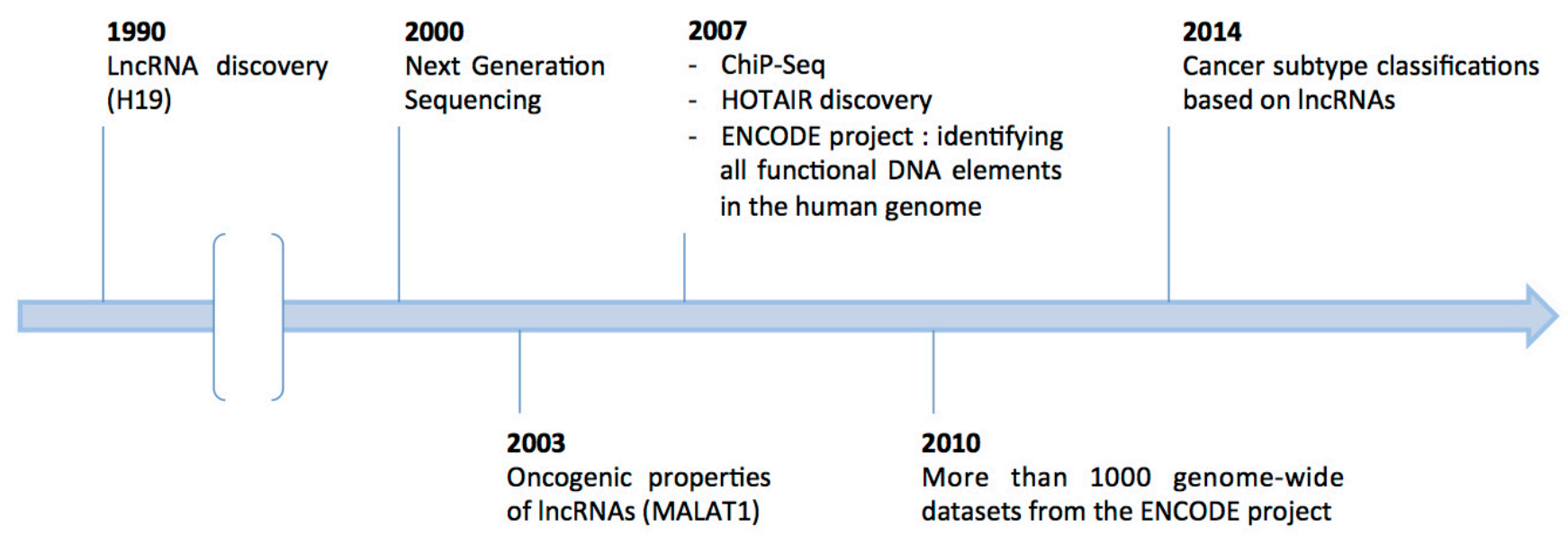

Figure 2: Major advances for IncRNA studies over time. 
hepatocellular carcinoma and TUG1 in lung cancer interact with $H O X$ development genes, namely $H O X A 13$ and $H O X B 7$ [53, 54], involved in numerous oncogenic processes, such as proliferation, motility and angiogenesis.

The importance of lncRNAs in oncogenic mechanisms is such that various new implications will undoubtedly be unveiled in the years to come. The association of driver oncogenic alterations with lncRNA deregulations opens the way to integrative classifications using coding and non-coding genome.

\section{LncRNA and anticancer treatments}

The importance of lncRNAs in the management of anticancer treatment is supported by their participation in drug resistance in cancer. In prostate cancer, numerous lncRNAs are associated with resistance to hormonal therapy: the oncogenic lncRNA NEAT1 is a transcriptional activator downtream of estrogen receptor $\alpha(\mathrm{ER} \alpha)$ and thus independent from androgen signaling [49], while lncRNAs PRNCR1 and PCGEM1 interact with and activate truncated androgen receptors, leading to androgen independent activation of androgen receptors [50]. In bladder cancer, the lncRNA UCA-1 induce resistance to cisplatin-based chemotherapy by upregulating the $\mathrm{Wnt} / \beta$ catenin pathway [55]. In ovarian cancer, expression of HOTAIR, evaluated in 309 patients, is reported to be associated with resistance to carboplatin-based regimens, of unknown mechanism [56].

Conversely, expression of some lncRNAs might be predictors of response to anticancer treatments. This is the case with CCAT-1, a superenhancer of MYC in colon cancer, which transcription is highly sensitive to bromodomain inhibitors in vitro [57].Thus, it becomes clear that future biomarker studies will have to focus on lncRNAs to tailor individual treatments and to identify and overcome therapeutic resistance.

\section{Crosstalks with the RNA machinery}

LncRNAs interactions include crosstalks with other RNA subtypes, such as messenger and micro-RNAs, creating a network of interactions that can be involved in cancer mechanisms. Notably, lncRNAs are involved in miRNA regulation: the lncRNA ANRIL interacts negatively with the micro-RNAs miR99A and miR449A to promote mTOR and E2F1 expression [37]. Conversely, miRNAs can regulate lncRNAs activity, such as miRNA141, which suppresses HOTAIR expression [58]. Interactions between RNA subtypes have been notably explored in esophageal squamous cell carcinomas, where it has been reported that defined sets of lncRNAs, miRNAs and mRNAs encompass similar oncogenic features, such as apoptosis inhibition, cell cycle activation, proliferation, invasion and metastasis [59]. This suggests that diverse RNA subtypes work in cooperation for the acquisition of cancer properties. As lncRNAs encompass $25 \%$ of total RNAs in the human cell (Figure 3), their interaction network must be further studied to better grasp the full role of RNA crosstalks in pathology [60].

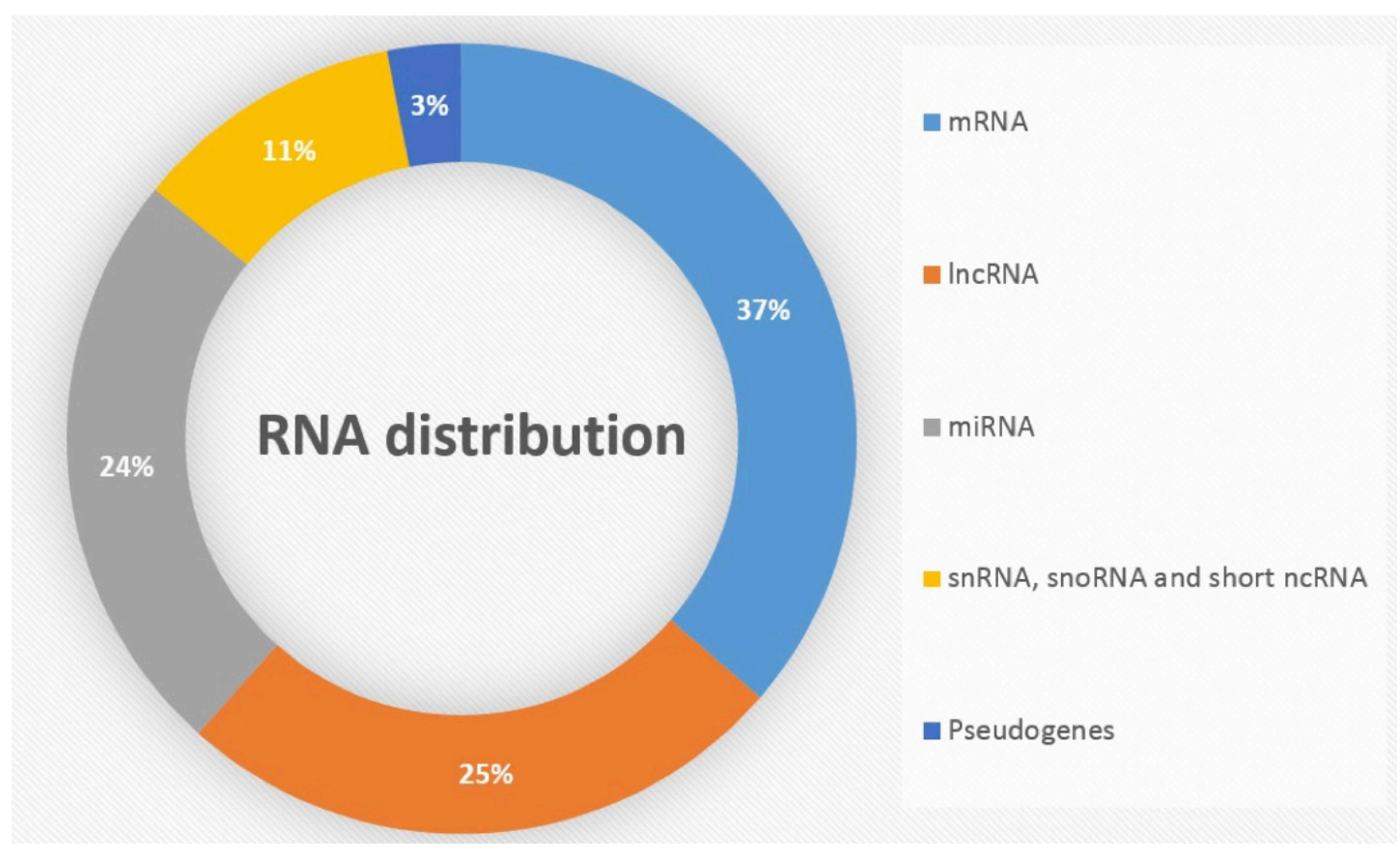

Figure 3: Distribution of RNA subtypes in human genome. Adapted from Atianand et al. [60]. lncRNAs: long non-coding RNAs, miRNAs: micro RNAs, short ncRNAs: short non-coding RNAs, snRNAs: small nuclear RNAs, snoRNAs: small nucleolar RNAs. 
Table 1: Cancer subtype classifications based on IncRNA expression profiles.

\begin{tabular}{|c|c|c|c|c|c|c|}
\hline Cancer type & $\begin{array}{l}\text { LncRNA database } \\
\text { and selected set }\end{array}$ & $\begin{array}{l}\text { Assessment of } \\
\text { IncRNA expression }\end{array}$ & $\mathbf{N}$ & LncRNA classification & Molecular alterations & Prognosis \\
\hline \multirow[t]{4}{*}{ Glioma } & \multirow{4}{*}{$\begin{array}{l}\text { Refseq, Ensembl } \\
1979 \text { IncRNAs with relevant } \\
\text { expression in glioma }\end{array}$} & \multirow[t]{4}{*}{ Microarrays } & \multirow[t]{4}{*}{284} & & & Overall survival \\
\hline & & & & IncR1 & Astroglial signature, EGFR amplification & Poor \\
\hline & & & & IncR2 & Neuronal signature, no recurrent alteration & Intermediate \\
\hline & & & & IncR3 & $\begin{array}{l}\text { Oligodendroglial signature, IDH1 mutation, } \\
1 \mathrm{p} / 19 \mathrm{q} \text { loss }\end{array}$ & Good \\
\hline \multirow[t]{3}{*}{ Colon } & \multirow{3}{*}{$\begin{array}{l}\text { GEO } \\
6 \text { IncRNAs associated with } \\
\text { prognosis in colon cancer }\end{array}$} & \multirow[t]{3}{*}{ Microarrays } & \multirow[t]{3}{*}{895} & & & DFS (150-months DFS) \\
\hline & & & & High risk & N/A & Poor $(51,49 \%)$ \\
\hline & & & & Low risk & N/A & Good $(78,09 \%)$ \\
\hline \multirow[t]{5}{*}{ Breast } & \multirow{5}{*}{$\begin{array}{l}\text { GENCODE } \\
1623 \text { IncRNAs with relevant } \\
\text { expression in breast cancer }\end{array}$} & \multirow[t]{5}{*}{ RNA-sequencing } & \multirow[t]{5}{*}{656} & & & Overall survival \\
\hline & & & & $\mathrm{C} 1$ & Basal-like & Good \\
\hline & & & & $\mathrm{C} 2$ & HER2-enriched & Poor \\
\hline & & & & $\mathrm{C3}$ & Luminal A & Good \\
\hline & & & & $\mathrm{C} 4$ & Luminal $A+$ luminal $B$ & Poor \\
\hline \multirow{5}{*}{$\begin{array}{l}\text { Renal cell } \\
\text { carcinoma }\end{array}$} & \multirow{5}{*}{$\begin{array}{l}\text { GENCODE } \\
1934 \text { IncRNAs with relevant } \\
\text { expression in renal cell } \\
\text { carcinoma }\end{array}$} & \multirow[t]{5}{*}{ RNA-sequencing } & \multirow[t]{5}{*}{475} & & & Overall survival (median) \\
\hline & & & & $\mathrm{C} 1$ & PBRM1 mutations, & Good $(7,64$ years $)$ \\
\hline & & & & $\mathrm{C} 2$ & $9 p$ deletion, BAP 1 mutations & Poor ( 3,33 years $)$ \\
\hline & & & & $\mathrm{C} 3$ & PBRM1 mutations & Good (not reached) \\
\hline & & & & $\mathrm{C} 4$ & Misclassified & Good (not reached) \\
\hline \multirow{4}{*}{$\begin{array}{l}\text { Endometrioid } \\
\text { endometrial } \\
\text { carcinoma }\end{array}$} & \multirow{4}{*}{$\begin{array}{l}\text { GENCODE } \\
1931 \text { IncRNAs with relevant } \\
\text { expression in endometrioid } \\
\text { endometrial carcinoma }\end{array}$} & \multirow[t]{4}{*}{ RNA-sequencing } & \multirow[t]{4}{*}{191} & & & \multirow[t]{4}{*}{ No distinct prognostic groups } \\
\hline & & & & Basal-like & $\begin{array}{l}\text { MSI, POLE, p53 mutations, } \\
\text { chromatin remodeling genes (EZH2, MLL) mutations }\end{array}$ & \\
\hline & & & & Luminal-like & ESR1, ERBB2 expression & \\
\hline & & & & CTNNB1-enriched & CTNNB1 mutations, PTEN loss & \\
\hline
\end{tabular}

GEO: Gene Expression Omnibus. DFS: disease free survival. EMT: epithelial mesenchymal trnasition. MSI: microsatellite instability, POLE: polymerase epsilon, N/A: not available

These data underscore the dramatic importance of lncRNAs in cancer. Interactions between lncRNAs and major oncogenic pathways support the role of IncRNAs in early steps of cancer development and their interest for more accurate cancer classifications. In addition, the unveiling of novel crosstalks between lncRNA and microRNAs raises the importance of epigenetic regulations in cancer, an expanding field of study.

\section{LNCRNAS PROFILING INTEGRATION IN CANCER CLASSIFICATIONS}

\section{LncRNAs as prognostic biomarkers}

As a result of the activation of oncogenic processes, lncRNA deregulations are associated with a more aggressive phenotype and drug resistance in cancer [13]. One of the first evidence of lncRNA involvement in cancer progression has been reported in breast cancer, where HOTAIR expression was being systematically increased compared to normal tissue. High expression of HOTAIR was associated with increased vascular invasion, advanced tumor stage, metastasis and poor prognosis [22]. In addition to breast cancer, overexpression of HOTAIR has been reported to be a marker for poor prognosis in various cancer types [61], including gastro-intestinal cancers [62, $63,64,65]$, urologic cancers [66, 67], gynecologic cancers $[68,69,70]$, lung cancers $[71,72]$ and undifferentiated carcinoma of nasopharyngeal type [73]. So far, numerous IncRNA have been associated with poor prognosis in subsets of tumors, such as SCHLAP1 in prostate cancer [74], HOTTIP in hepatocellular carcinoma [53], gastric cancer [75] and colon cancer [76], or FAL1 in ovarian cancer [77]. Other are associated with good prognosis, such as NBAT-1 in neuroblastoma [78] or NKILA in breast cancer [79]. The most striking evidence of their prognostic impact come from a large-scale pan-cancer analysis conducted on 15 cancer types, which reported that 32 to $310 \operatorname{lncRNAs}$ in each tumor had prognostic relevance [80].

Thus, IncRNAs might be considered as putative relevant prognostic markers for the clinic. As such, high expression of the IncRNA ENSG00000261582 is an independent marker of poor overall survival in lung and ovarian cancer in multivariate analysis [81]. Other robust studies indicate that high expression of HOTAIR in estrogen receptor negative breast cancer independently associated with lower overall survival in 
multivariate analysis $[22,82]$. These observations provide the proof of concept that lncRNAs might be potent and discriminative prognostic markers, which can bring independent information from genomic, proteomic or clinicopathological features.

Thus, it seems crucial to take into account lncRNAs profiling to improve current cancer classifications, and conduct integrative analyses with known clinical, pathological and molecular features of cancers $[83,84]$.

\section{Integrative classifications}

Du et al. report the first study assessing the role of lncRNAs in subtype classifications of 1,300 tissue samples among 4 different subtypes of cancer: ovarian, prostatic, lung SCC and glioma [81]. In this study, microarrays analyses have been performed to determine the lncRNAs expression profiles, with probes covering more than 10,000 lncRNAs identified through Ensembl and RefSeq sequence databases spanning the entire genome. LncRNAs were shown to display a specific expression pattern that correlated with established genomic classification in ovarian cancer, glioma, and lung squamous cell carcinoma. In ovarian cancer, unsupervised lncRNAs clustering identifed four groups of tumors matching with immunoreactive, mesenchymal, proliferative, and differentiated genomic profiles. In glioma, four groups were correlated with the classical, neural, proneural and mesenchymal profiles. In lung squamous cell carcinoma, lncRNA expression matched with basal, primitive, classical, and secretory-type gene expression profiling. The association between coding genome and lncRNAs points the relevance of lncRNA profiling to establish cancer subtypes classification. As lncRNA profiles can be established using RNAseq data that tend to be increasingly accessible, we believe that lncRNA profiling will be of great importance in the coming future.

Already, several reports explored the impact of lncRNA in cancer subtype classifications in different localizations including glioma, colon, breast, renal and endometrial cancers (Table 1). In glioma, the most frequent subtype of primitive brain tumors, consensus clustering of lncRNAs using 425 cases revealed three molecular subtypes: lncR1, $\operatorname{lncR} 2$ and $\operatorname{lncR} 3$ [85]. LncR1 subtype was associated with astroglial gene signature, epidermal growth factor (EGFR) amplification and patients displayed poor overall survival. On the contrary, lncR3 subtype correlated with oligodendritic gene signature, IDH1 mutation, $1 \mathrm{p} / 19 \mathrm{q}$ chromosomal deletions and patients had good prognosis. Finally, lncR2 represented an intermediary subtype regarding prognostic, with neuronal gene signature. Interestingly, this lncRNA classification correlates with various molecular prognostic factors, but it is still unknown whether lncRNA alterations are bound to specific genetic mutations such as IDH1, or chromatin remodeling genes alterations.
In colon cancer, a prognostic signature for diseasefree survival has been established from six lncRNA which expression was strongly correlated with prognosis. This signature has been validated in 459 patients using the Gene Expression Omnibus (GEO) database [86]. This signature divides the population into two subgroups: highand low-risk, according to lncRNA expression. However, stratification using the combination of both clinical staging (stages I/II $v$ stages III/IV) and lncRNA signature (highrisk $v$ low-risk) was capable to subdivide the patients into 4 groups with significantly distinct disease-free survival. This indicates that patients' stratification might be improved using integrative analysis of lncRNAs and clinical data. This study does not specify the presence of associated alterations, such as a deficient mismatch repair (dMMR) or a methylator phenotype (CIMP). Considering that lncRNAs act as broad epigenetic regulators, exploration of interactions between CIMP and lncRNA should be of great interest for the next future of colon cancer management.

In invasive breast cancer, we recently reported the lncRNAs portrait of 658 tumors and compared the data with the genomic PAM50 classification [87]. PAM50 is a molecular classification that identified four breast cancer subgroups, based on transcription profiling: basal-like, HER-2 enriched, luminal A, and luminal B. As PAM50 classification, we identified four clusters of lncRNAs clusters of lncRNAs have been identified. Those clusters correlated with PAM50 classification. Of note, while the three IncRNA clusters C1, C2 and C3 associated with basal-like, HER-2 enriched and luminal A groups and were highly correlated with their relative PAM50 mRNA classification, cluster C4 was not. Indeed, although C4 lncRNA cluster was associated with luminal signature and estrogen receptor (ER) expression, $\mathrm{C} 4$ cluster was not clearly capable of differentiating luminal $\mathrm{A}$ and luminal B subgroups. Thus, future studies are needed to explore the links between lncRNAs and estrogen receptors in breast cancers, as it is the case for H19 and HOTAIR [88, 89]. In addition, the relevance of IncRNA for prognostic classifications in breast cancer must be confronted to validated genomic classifications for the prediction of recurrence and prognosis in use in clinical routine [90].

Another cancer where lncRNA is important in defining tissue-specificity is clear-cell renal cell carcinoma (ccRCC). In 2010, ccRCCs have been classified in two molecular subgroups, type A and B, with distinct diseasefree survival [91]. Effort form the TCGA working group helped identify four distinct subgroups with different outcomes, based on mRNA and miRNA expression [92]. More recently, using unsupervised lncRNA clustering of 475 primary tumor samples from the Cancer Genome Atlas, we reported four distinct lncRNA subgroups of ccRCCs associated with distinct prognosis, pathological features and molecular alterations, including specific alterations of chromatin-remodeling genes [93]. The 
prognostic value of lncRNA profiling was found to be independent from pathological grade and TNM stage. Cluster 2 was enriched for tumors harboring mutations in the chromatin-remodeling gene $B A P 1$, and was strongly associated with high tumor grade and poor prognosis. In contrast, two clusters with better prognosis displayed PBRM1 mutations, a component of SWI/SNF transcriptional activator. This suggests that ccRCCs subtypes have different epigenetic landscape alterations, which are closely linked with their lncRNA expression profile. However, how those lncRNAs are interacting with PBRM1 and BAP1 remains to be explored. Of note, one subgroup was composed of misclassified tumours (chromophobe RCC and translocation RCC), suggesting the importance of lncRNAs in defining cell ontogeny.

Recent work focused on endometrioid endometrial carcinoma, the most frequent subtype of endometrial adenocarcinoma and usually associated with good prognosis. Unsupervised clustering of 1,931 lncRNAs significantly expressed in endometrioid endometrial carcinoma identified 3 subgroups: basal-like, luminal-like and CTNNB1-enriched [94]. Basal-like and luminal-like subgroups shared similarities for lncRNAs expression compared to their equivalent breast cancer subtype. The luminal subgroup was associated with expression of progesterone (PGR) and estrogen receptor (ESR1) genes, while the CTNNB1 subgroup involved mutations in the $\beta$-catenin gene and PTEN loss. There was a trend towards poorer survival in the basal-like subgroup, which included more aggressive tumors that were enriched for p53 mutations and mutations of the $M L L$ genes family. The interplay between lncRNA subtyping and alterations of chromatin remodeling genes might be an interesting area for the development of innovative therapies in this indication.

These studies suggest that IncRNA expression profile is correlated with genomic, genetic, pathological and clinical features of diverse neoplasms, but also brings independent prognostic value in various subsets of tumors. As such, lncRNAs are likely to be integrated in cancer classifications during the next decades.

\section{PERSPECTIVES}

LncRNAs represent a new class of cancer cell regulators involved in diverse mechanism of oncogenesis, with new implications unveiled continuously. In the largest study to date, transcriptomic analysis of 91,013 expressed human genes in more than 7,256 tissue samples have shown that lncRNA may represent nearly $70 \%$ of human transcripts [95]. This number is considerably higher than expected, as IncRNA represented only $25 \%$ of the transcriptome in other series. This indicates that lncRNAs might outnumber coding RNAs by a large margin, which suggests that their importance in human biology is underestimated. In addition, precise understanding of the mechanisms involved in genome-wide epigenetic regulation is not fully fleshed out. Common patterns might be responsible for epigenetic regulation associated with different RNA systems [96]. To better understand these associations, integrative analysis of non-coding RNAs localizations and chromatin-RNA interactions across the tumor genome are needed. Further investigations are also underway to better understand the networks involving both coding and non-coding RNA machinery, regulating cellular processes [97]. International efforts are being made with the creation of participative RNA databases and computer-based simulations for molecular interactions, such as RNAbase [98], IncRNATor [99], and Cupid [100] projects, that will help further encompass the complexity and the promising potential of lncRNAs.

LncRNAs are relevant and potent biomarkers for cancer subtype analyses and prognostic stratifications with tissue-specific expression. Their implementation in clinical practice is around the corner, pending validation studies to assess the reproducibility of those classifications and the input of their integration in patient's management. Development of therapies targeting lncRNAs will be a major challenge. Previous attempts at RNA targeting faced difficulties for treatment distribution in the tumor site, which remain to be resolved [101]. The concurrent development of biomarkers will be of great interest in the fields of diagnosis, prognosis assessment, and prediction to identify the population eligible to future treatments targeting lncRNAs. New insights might be provided through the emergence of liquid biopsies. Indeed, HOTAIR, HULC and H19 expression levels in plasma have been demonstrated to correlate with outcome in series of patients with metastatic colon cancer [102], hepatocellular carcinoma [103] and gastric cancer [104], respectively. This is of high interest considering the possibilities of using lncRNAs as potent circulating biomarkers.

As lncRNA profiling represents an exciting tool in cancer management, its implementation will be a key player in the integration of molecular medicine into clinical practice and personalized care.

\section{CONFLICTS OF INTERESTS}

The authors declare that they have no competing interests.

\section{REFERENCES}

1. Heng DYC, Xie W, Regan MM, Warren MA, Golshayan AR, Sahi C, Eigl BJ, Ruether JD, Cheng T, North S, Venner P, Knox JJ, Chi KN, et al. Prognostic Factors for Overall Survival in Patients With Metastatic Renal Cell Carcinoma Treated With Vascular Endothelial Growth Factor-Targeted Agents: Results From a Large, Multicenter Study. J Clin Oncol. 2009 Dec 1;27:5794-9. 
2. Viale G. The current state of breast cancer classification. Ann Oncol. 2012 Sep 1;23:x207-10.

3. Sargent DJ, Marsoni S, Monges G, Thibodeau SN, Labianca R, Hamilton SR, French AJ, Kabat B, Foster NR, Torri V, Ribic C, Grothey A, Moore M, et al. Defective mismatch repair as a predictive marker for lack of efficacy of fluorouracil-based adjuvant therapy in colon cancer. J Clin Oncol Off J Am Soc Clin Oncol. 2010 Jul 10;28:3219-26.

4. Parker JS, Mullins M, Cheang MCU, Leung S, Voduc D, Vickery T, Davies S, Fauron C, He X, Hu Z, Quackenbush JF, Stijleman IJ, Palazzo J, et al. Supervised Risk Predictor of Breast Cancer Based on Intrinsic Subtypes. J Clin Oncol. 2009 Mar 10;27:1160-7.

5. Sparano JA, Gray RJ, Makower DF, Pritchard KI, Albain KS, Hayes DF, Geyer CE, Dees EC, Perez EA, Olson JA, Zujewski J, Lively T, Badve SS, et al. Prospective Validation of a 21-Gene Expression Assay in Breast Cancer. N Engl J Med. 2015 Nov 19;373:2005-14.

6. Turcan S, Rohle D, Goenka A, Walsh LA, Fang F, Yilmaz E, Campos C, Fabius AWM, Lu C, Ward PS, Thompson CB, Kaufman A, Guryanova O, et al. IDH1 mutation is sufficient to establish the glioma hypermethylator phenotype. Nature. 2012 Mar 22;483:479-83.

7. Yang H, Ye D, Guan K-L, Xiong Y. IDH1 and IDH2 Mutations in Tumorigenesis: Mechanistic Insights and Clinical Perspectives. Clin Cancer Res. 2012 Oct 15;18:5562-71.

8. IDH1 inhibitor shows promising early results. Cancer Discov. 2015 Jan;5:4.

9. Shaw AT, Kim D-W, Nakagawa K, Seto T, Crinó L, Ahn M-J, De Pas T, Besse B, Solomon BJ, Blackhall F, Wu Y-L, Thomas M, O’Byrne KJ, et al. Crizotinib versus Chemotherapy in Advanced ALK-Positive Lung Cancer. N Engl J Med. 2013 Jun 20;368:2385-94.

10. Gridelli C, De Marinis F, Di Maio M, Cortinovis D, Cappuzzo F, Mok T. Gefitinib as first-line treatment for patients with advanced non-small-cell lung cancer with activating epidermal growth factor receptor mutation: Review of the evidence. Lung Cancer Amst Neth. 2011 Mar;71:249-57.

11. Nagaraja AK, Bass AJ. Hitting the Target in BRAFMutant Colorectal Cancer. J Clin Oncol. 2015 Oct 12; JCO.2015.63.7793.

12. Xue B, He L. An expanding universe of the noncoding genome in cancer biology. Carcinogenesis. 2014 Jun;35:1209-16.

13. Prensner JR, Chinnaiyan AM. The emergence of lncRNAs in cancer biology. Cancer Discov. 2011 Oct;1:391-407.

14. Alam T, Medvedeva YA, Jia H, Brown JB, Lipovich L, Bajic VB. Promoter Analysis Reveals Globally Differential Regulation of Human Long Non-Coding RNA and ProteinCoding Genes. PLoS One. 2014 Oct 2;9:e109443. doi: 10.1371/journal.pone.0109443. eCollection 2014.

15. Quinn JJ, Chang HY. Unique features of long non-coding
RNA biogenesis and function. Nat Rev Genet. 2016 Jan; 17:47-62.

16. Rinn JL, Chang HY. Genome regulation by long noncoding RNAs. Annu Rev Biochem. 2012;81:145-66.

17. Guttman M, Rinn JL. Modular regulatory principles of large non-coding RNAs. Nature. 2012 Feb 15;482:339-46.

18. Derrien T, Johnson R, Bussotti G, Tanzer A, Djebali S, Tilgner H, Guernec G, Martin D, Merkel A, Knowles DG, Lagarde J, Veeravalli L, Ruan X, et al. The GENCODE v7 catalog of human long noncoding RNAs: Analysis of their gene structure, evolution, and expression. Genome Res. 2012 Sep;22:1775-89.

19. St. Laurent G, Wahlestedt C, Kapranov P. The Landscape of long noncoding RNA classification. Trends Genet. 2015 May;31:239-51.

20. Calin GA, Liu C, Ferracin M, Hyslop T, Spizzo R, Sevignani C, Fabbri M, Cimmino A, Lee EJ, Wojcik SE, Shimizu M, Tili E, Rossi S, et al. Ultraconserved Regions Encoding ncRNAs Are Altered in Human Leukemias and Carcinomas. Cancer Cell. 2007 Sep 11;12:215-29.

21. Fatica A, Bozzoni I. Long non-coding RNAs: new players in cell differentiation and development. Nat Rev Genet. 2014 Jan;15:7-21.

22. Gupta RA, Shah N, Wang KC, Kim J, Horlings HM, Wong DJ, Tsai M-C, Hung T, Argani P, Rinn JL, Wang Y, Brzoska P, Kong B, et al. Long non-coding RNA HOTAIR reprograms chromatin state to promote cancer metastasis. Nature. 2010 Apr 15;464:1071-6.

23. Lu L, Zhu G, Zhang C, Deng Q, Katsaros D, Mayne ST, Risch HA, Mu L, Canuto EM, Gregori G, Benedetto C, $\mathrm{Yu}$ H. Association of large noncoding RNA HOTAIR expression and its downstream intergenic $\mathrm{CpG}$ island methylation with survival in breast cancer. Breast Cancer Res Treat. 2012 Dec;136:875-83.

24. Sørensen KP, Thomassen M, Tan Q, Bak M, Cold S, Burton M, Larsen MJ, Kruse TA. Long non-coding RNA HOTAIR is an independent prognostic marker of metastasis in estrogen receptor-positive primary breast cancer. Breast Cancer Res Treat. 2013 Dec;142:529-36.

25. Beckedorff FC, Amaral MS, Deocesano-Pereira C, Verjovski-Almeida S. Long non-coding RNAs and their implications in cancer epigenetics. Biosci Rep. 2013;33.

26. Mercer TR, Mattick JS. Structure and function of long noncoding RNAs in epigenetic regulation. Nat Struct Mol Biol. 2013 Mar;20:300-7.

27. Pasmant E, Sabbagh A, Vidaud M, Bièche I. ANRIL, a long, noncoding RNA, is an unexpected major hotspot in GWAS. FASEB J Off Publ Fed Am Soc Exp Biol. 2011 Feb;25:444-8.

28. Schmitt AM, Chang HY. Long Noncoding RNAs in Cancer Pathways. Cancer Cell. 2016 avril;29:452-63.

29. Tseng Y-Y, Moriarity BS, Gong W, Akiyama R, Tiwari A, Kawakami H, Ronning P, Reuland B, Guenther K, Beadnell TC, Essig J, Otto GM, O'Sullivan MG, et al. PVT1 
dependence in cancer with MYC copy-number increase. Nature. 2014 Aug 7;512:82-6. doi: 10.1038/nature13311.

30. Liao L-M, Sun X-Y, Liu A-W, Wu J-B, Cheng X-L, Lin $\mathrm{J}-\mathrm{X}$, Zheng M, Huang L. Low expression of long noncoding XLOC_010588 indicates a poor prognosis and promotes proliferation through upregulation of c-Myc in cervical cancer. Gynecol Oncol. 2014 Jun;133:616-23.

31. He X, Tan X, Wang X, Jin H, Liu L, Ma L, Yu H, Fan Z. C-Myc-activated long noncoding RNA CCAT1 promotes colon cancer cell proliferation and invasion. Tumour Biol J Int Soc Oncodevelopmental Biol Med. 2014 Dec;35:121818 .

32. Barsyte-Lovejoy D, Lau SK, Boutros PC, Khosravi F, Jurisica I, Andrulis IL, Tsao MS, Penn LZ. The c-Myc oncogene directly induces the H19 noncoding RNA by allele-specific binding to potentiate tumorigenesis. Cancer Res. 2006 May 15;66:5330-7.

33. Zhang $\mathrm{A}, \mathrm{Xu} \mathrm{M}$, Mo $\mathrm{Y}-\mathrm{Y}$. Role of the lncRNAp53 regulatory network in cancer. J Mol Cell Biol. 2014 Apr 9;mju013.

34. Huarte M, Guttman M, Feldser D, Garber M, Koziol MJ, Kenzelmann-Broz D, Khalil AM, Zuk O, Amit I, Rabani M, Attardi LD, Regev A, Lander ES, et al. A Large Intergenic Noncoding RNA Induced by p53 Mediates Global Gene Repression in the p53 Response. Cell. 2010 Aug 6;142:40919.

35. Pickard MR, Mourtada-Maarabouni M, Williams GT. Long non-coding RNA GAS5 regulates apoptosis in prostate cancer cell lines. Biochim Biophys Acta BBA - Mol Basis Dis. 2013 Oct;1832:1613-23.

36. Pickard MR, Williams GT. Regulation of apoptosis by long non-coding RNA GAS5 in breast cancer cells: implications for chemotherapy. Breast Cancer Res Treat. 2014 May 1;145:359-70.

37. Zhang E, Kong R, Yin D, You L, Sun M, Han L, Xu T, Xia $\mathrm{R}$, Yang J, De W, Chen J fei. Long noncoding RNA ANRIL indicates a poor prognosis of gastric cancer and promotes tumor growth by epigenetically silencing of $\mathrm{miR}-99 \mathrm{a} / \mathrm{miR}$ 449a. Oncotarget. 2014 Apr 30;5:2276-92. doi: 10.18632/ oncotarget.1902.

38. Goedert L, Pereira CG, Roszik J, Plaça JR, Cardoso C, Chen G, Deng W, Yennu-Nanda VG, Jr WAS, Davies MA, Espreafico EM, Goedert L, Pereira CG, et al. RMEL3, a novel BRAF V600E -associated long noncoding RNA, is required for MAPK and PI3K signaling in melanoma. Oncotarget. 2016 May 4. doi: 10.18632/oncotarget.9164

39. Johnsson P, Ackley A, Vidarsdottir L, Lui W-O, Corcoran M, Grandér D, Morris KV. A pseudogene long-noncodingRNA network regulates PTEN transcription and translation in human cells. Nat Struct Mol Biol. 2013 avril;20:440-6.

40. Poliseno L, Salmena L, Zhang J, Carver B, Haveman WJ, Pandolfi PP. A coding-independent function of gene and pseudogene mRNAs regulates tumour biology. Nature. 2010 juin;465:1033-8.
41. Zhang Z-X, Liu Z-Q, Jiang B, Lu X-Y, Ning X-F, Yuan C-T, Wang A-L. BRAF activated non-coding RNA (BANCR) promoting gastric cancer cells proliferation via regulation of NF-B1. Biochem Biophys Res Commun. 2015 Sep 18;465:225-31.

42. Lu Z, Xiao Z, Liu F, Cui M, Li W, Yang Z, Li J, Ye L, Zhang X. Long non-coding RNA HULC promotes tumor angiogenesis in liver cancer by up-regulating sphingosine kinase 1 (SPHK1). Oncotarget. 2016 Jan 5;7:241-54. doi: 10.18632/oncotarget.6280.

43. Yuan S-X, Yang F, Yang Y, Tao Q-F, Zhang J, Huang G, Yang Y, Wang R-Y, Yang S, Huo X-S, Zhang L, Wang F, Sun S-H, et al. Long noncoding RNA associated with microvascular invasion in hepatocellular carcinoma promotes angiogenesis and serves as a predictor for hepatocellular carcinoma patients' poor recurrence-free survival after hepatectomy. Hepatol Baltim Md. 2012 Dec;56:2231-41.

44. Fan Y, Shen B, Tan M, Mu X, Qin Y, Zhang F, Liu Y. TGF--induced upregulation of malat1 promotes bladder cancer metastasis by associating with suz12. Clin Cancer Res Off J Am Assoc Cancer Res. 2014 Mar 15;20:1531-41.

45. Hu Y, Wang J, Qian J, Kong X, Tang J, Wang Y, Chen $\mathrm{H}$, Hong J, Zou W, Chen Y, Xu J, Fang J-Y. Long noncoding RNA GAPLINC regulates CD44-dependent cell invasiveness and associates with poor prognosis of gastric cancer. Cancer Res. 2014 Dec 1;74:6890-902.

46. Nie F-Q, Zhu Q, Xu T-P, Zou Y-F, Xie M, Sun M, Xia R, Lu K-H. Long non-coding RNA MVIH indicates a poor prognosis for non-small cell lung cancer and promotes cell proliferation and invasion. Tumour Biol J Int Soc Oncodevelopmental Biol Med. 2014 Aug;35:7587-94.

47. Wu Z-H, Wang X-L, Tang H-M, Jiang T, Chen J, Lu S, Qiu G-Q, Peng Z-H, Yan D-W. Long non-coding RNA HOTAIR is a powerful predictor of metastasis and poor prognosis and is associated with epithelial-mesenchymal transition in colon cancer. Oncol Rep. 2014 Jul;32:395-402.

48. Sun M, Liu X-H, Wang K-M, Nie F, Kong R, Yang J, Xia R, Xu T-P, Jin F-Y, Liu Z-J, Chen J, Zhang E-B, De W, et al. Downregulation of BRAF activated non-coding RNA is associated with poor prognosis for non-small cell lung cancer and promotes metastasis by affecting epithelialmesenchymal transition. Mol Cancer. 2014;13:68.

49. Chakravarty D, Sboner A, Nair SS, Giannopoulou E, Li R, Hennig S, Mosquera JM, Pauwels J, Park K, Kossai M, MacDonald TY, Fontugne J, Erho N, et al. The oestrogen receptor alpha-regulated lncRNA NEAT1 is a critical modulator of prostate cancer. Nat Commun. 2014 Nov 21;5:5383. doi: 10.1038/ncomms6383.

50. Yang L, Lin C, Jin C, Yang JC, Tanasa B, Li W, Merkurjev D, Ohgi KA, Meng D, Zhang J, Evans CP, Rosenfeld MG. lncRNA-dependent mechanisms of androgen-receptorregulated gene activation programs. Nature. 2013 Aug 29;500:598-602.

51. Montes M, Nielsen MM, Maglieri G, Jacobsen A, Højfeldt 
J, Agrawal-Singh S, Hansen K, Helin K, van de Werken HJG, Pedersen JS, Lund AH. The IncRNA MIR31HG regulates p16INK4A expression to modulate senescence. Nat Commun. 2015 avril;6:6967.

52. Aguilo F, Zhou M-M, Walsh MJ. Long noncoding RNA, polycomb, and the ghosts haunting INK4b-ARF-INK4a expression. Cancer Res. 2011 Aug 15;71:5365-9.

53. Quagliata L, Matter MS, Piscuoglio S, Arabi L, Ruiz C, Procino A, Kovac M, Moretti F, Makowska Z, Boldanova T, Andersen JB, Hämmerle M, Tornillo L, et al. Long noncoding RNA HOTTIP/HOXA13 expression is associated with disease progression and predicts outcome in hepatocellular carcinoma patients. Hepatol Baltim Md. 2014 Mar;59:911-23.

54. Zhang E, Yin D, Sun M, Kong R, Liu X, You L, Han L, Xia R, Wang K, Yang J, De W, Shu Y, Wang Z. P53-regulated long non-coding RNA TUG1 affects cell proliferation in human non-small cell lung cancer, partly through epigenetically regulating HOXB7 expression. Cell Death Dis. 2014;5:e1243.

55. Fan Y, Shen B, Tan M, Mu X, Qin Y, Zhang F, Liu Y. Long non-coding RNA UCA1 increases chemoresistance of bladder cancer cells by regulating Wnt signaling. FEBS J. 2014 Apr 1;281:1750-8.

56. Teschendorff AE, Lee S-H, Jones A, Fiegl H, Kalwa M, Wagner W, Chindera K, Evans I, Dubeau L, Orjalo A, Horlings HM, Niederreiter L, Kaser A, et al. HOTAIR and its surrogate DNA methylation signature indicate carboplatin resistance in ovarian cancer. Genome Med. 2015;7:108.

57. McCleland ML, Mesh K, Lorenzana E, Chopra VS, Segal E, Watanabe C, Haley B, Mayba O, Yaylaoglu M, Gnad F, Firestein R. CCAT1 is an enhancer-templated RNA that predicts BET sensitivity in colorectal cancer. J Clin Invest. 2016 Jan 11;126:639-52.

58. Chiyomaru T, Fukuhara S, Saini S, Majid S, Deng G, Shahryari V, Chang I, Tanaka Y, Enokida H, Nakagawa M, Dahiya R, Yamamura S. Long non-coding RNA HOTAIR is targeted and regulated by miR-141 in human cancer cells. J Biol Chem. 2014 May 2;289:12550-65.

59. Li S-Q, Li F, Xiao Y, Wang C-M, Tuo L, Hu J, Yang X-B, Wang J-S, Shi W-H, Li X, Cao X-F. Comparison of long non-coding RNAs, microRNAs and messenger RNAs involved in initiation and progression of esophageal squamous cell carcinoma. Mol Med Rep. 2014 Aug;10:65262.

60. Atianand MK, Fitzgerald KA. Long non-coding RNAs and control of gene expression in the immune system. Trends Mol Med. 2014 Nov;20:623-31.

61. Cai B, Wu Z, Liao K, Zhang S. Long noncoding RNA HOTAIR can serve as a common molecular marker for lymph node metastasis: a meta-analysis. Tumour Biol J Int Soc Oncodevelopmental Biol Med. 2014 Sep;35:8445-50.
62. Niinuma T, Suzuki H, Nojima M, Nosho K, Yamamoto H, Takamaru H, Yamamoto E, Maruyama R, Nobuoka T, Miyazaki Y, Nishida T, Bamba T, Kanda T, et al. Upregulation of miR-196a and HOTAIR drive malignant character in gastrointestinal stromal tumors. Cancer Res. 2012 Mar 1;72:1126-36.

63. Kogo R, Shimamura T, Mimori K, Kawahara K, Imoto S, Sudo T, Tanaka F, Shibata K, Suzuki A, Komune S, Miyano S, Mori M. Long noncoding RNA HOTAIR regulates polycomb-dependent chromatin modification and is associated with poor prognosis in colorectal cancers. Cancer Res. 2011 Oct 15;71:6320-6.

64. Lv X-B, Lian G-Y, Wang H-R, Song E, Yao H, Wang M-H. Long noncoding RNA HOTAIR is a prognostic marker for esophageal squamous cell carcinoma progression and survival. PloS One. 2013;8:e63516.

65. Kim K, Jutooru I, Chadalapaka G, Johnson G, Frank J, Burghardt R, Kim S, Safe S. HOTAIR is a negative prognostic factor and exhibits pro-oncogenic activity in pancreatic cancer. Oncogene. 2013 Mar 28;32:1616-25.

66. Yan T-H, Lu S-W, Huang Y-Q, Que G-B, Chen J-H, Chen Y-P, Zhang H-B, Liang X-L, Jiang J-H. Upregulation of the long noncoding RNA HOTAIR predicts recurrence in stage $\mathrm{Ta} / \mathrm{T} 1$ bladder cancer. Tumour Biol J Int Soc Oncodevelopmental Biol Med. 2014 Oct;35:10249-57.

67. Wu Y, Liu J, Zheng Y, You L, Kuang D, Liu T. Suppressed expression of long non-coding RNA HOTAIR inhibits proliferation and tumourigenicity of renal carcinoma cells. Tumour Biol J Int Soc Oncodevelopmental Biol Med. 2014 Dec;35:11887-94.

68. He X, Bao W, Li X, Chen Z, Che Q, Wang H, Wan X-P. The long non-coding RNA HOTAIR is upregulated in endometrial carcinoma and correlates with poor prognosis. Int J Mol Med. 2014 Feb;33:325-32.

69. Qiu J, Lin Y, Ye L, Ding J, Feng W, Jin H, Zhang Y, Li Q, Hua K. Overexpression of long non-coding RNA HOTAIR predicts poor patient prognosis and promotes tumor metastasis in epithelial ovarian cancer. Gynecol Oncol. 2014 Jul;134:121-8.

70. Huang L, Liao L-M, Liu A-W, Wu J-B, Cheng X-L, Lin J-X, Zheng M. Overexpression of long noncoding RNA HOTAIR predicts a poor prognosis in patients with cervical cancer. Arch Gynecol Obstet. 2014 Oct;290:717-23.

71. Liu X, Liu Z, Sun M, Liu J, Wang Z, De W. The long non-coding RNA HOTAIR indicates a poor prognosis and promotes metastasis in non-small cell lung cancer. BMC Cancer. 2013;13:464.

72. Nakagawa T, Endo H, Yokoyama M, Abe J, Tamai K, Tanaka N, Sato I, Takahashi S, Kondo T, Satoh K. Large noncoding RNA HOTAIR enhances aggressive biological behavior and is associated with short disease-free survival in human non-small cell lung cancer. Biochem Biophys Res Commun. 2013 Jun 28;436:319-24. 
73. Nie Y, Liu X, Qu S, Song E, Zou H, Gong C. Long noncoding RNA HOTAIR is an independent prognostic marker for nasopharyngeal carcinoma progression and survival. Cancer Sci. 2013 Apr;104:458-64.

74. Prensner JR, Zhao S, Erho N, Schipper M, Iyer MK, Dhanasekaran SM, Magi-Galluzzi C, Mehra R, Sahu A, Siddiqui J, Davicioni E, Den RB, Dicker AP, et al. RNA biomarkers associated with metastatic progression in prostate cancer: a multi-institutional high-throughput analysis of SChLAP1. Lancet Oncol. 2014 Dec;15:1469-80.

75. Chang S, Liu J, Guo S, He S, Qiu G, Lu J, Wang J, Fan L, Zhao W, Che X. HOTTIP and HOXA13 are oncogenes associated with gastric cancer progression. Oncol Rep. 2016 Jun;35:3577-85.

76. Ren Y-K, Xiao Y, Wan X-B, Zhao Y-Z, Li J, Li Y, Han G-S, Chen X-B, Zou Q-Y, Wang G-C, Lu C-M, Xu Y-C, Wang Y-C. Association of long non-coding RNA HOTTIP with progression and prognosis in colorectal cancer. Int $\mathrm{J}$ Clin Exp Pathol. 2015;8:11458-63.

77. Hu X, Feng Y, Zhang D, Zhao SD, Hu Z, Greshock J, Zhang Y, Yang L, Zhong X, Wang L-P, Jean S, Li C, Huang $Q$, et al. A functional genomic approach identifies FAL1 as an oncogenic long noncoding RNA that associates with BMI1 and represses p21 expression in cancer. Cancer Cell. 2014 Sep 8;26:344-57.

78. Pandey GK, Mitra S, Subhash S, Hertwig F, Kanduri M, Mishra K, Fransson S, Ganeshram A, Mondal T, Bandaru S, Östensson M, Akyürek LM, Abrahamsson J, et al. The Risk-Associated Long Noncoding RNA NBAT1 Controls Neuroblastoma Progression by Regulating Cell Proliferation and Neuronal Differentiation. Cancer Cell. 2014 Nov 10;26:722-37.

79. Liu B, Sun L, Liu Q, Gong C, Yao Y, Lv X, Lin L, Yao H, Su F, Li D, Zeng M, Song E. A cytoplasmic NF-B interacting long noncoding RNA blocks IB phosphorylation and suppresses breast cancer metastasis. Cancer Cell. 2015 Mar 9;27:370-81.

80. Wang Z-L, Li B, Piccolo SR, Zhang X-Q, Li J-H, Zhou $\mathrm{H}$, Yang J-H, Qu L-H. Integrative analysis reveals clinical phenotypes and oncogenic potentials of long non-coding RNAs across 15 cancer types. Oncotarget. 2016 Apr 27; doi: 10.18632/oncotarget.9037.

81. Du Z, Fei T, Verhaak RGW, Su Z, Zhang Y, Brown M, Chen Y, Liu XS. Integrative genomic analyses reveal clinically relevant long noncoding RNAs in human cancer. Nat Struct Mol Biol. 2013 Jul;20:908-13.

82. Gökmen-Polar Y, Vladislav IT, Neelamraju Y, Janga SC, Badve S. Prognostic Impact of HOTAIR Expression is Restricted to ER-Negative Breast Cancers. Sci Rep. 2015 Mar 5;5:8765. doi: 10.1038/srep08765.

83. Zhou S, Wang J, Zhang Z. An emerging understanding of long noncoding RNAs in kidney cancer. J Cancer Res Clin Oncol. 2014 Dec;140:1989-95.

84. Zhang H, Chen Z, Wang X, Huang Z, He Z, Chen Y. Long non-coding RNA: a new player in cancer. J Hematol OncolJ Hematol Oncol. 2013 May 31;6:37.

85. Li R, Qian J, Wang Y-Y, Zhang J-X, You Y-P. Long noncoding RNA profiles reveal three molecular subtypes in glioma. CNS Neurosci Ther. 2014 Apr;20:339-43.

86. $\mathrm{Hu}$ Y, Chen H-Y, Yu C-Y, Xu J, Wang J-L, Qian J, Zhang $\mathrm{X}$, Fang J-Y. A long non-coding RNA signature to improve prognosis prediction of colorectal cancer. Oncotarget. 2014 Apr 11;5:2230-42. doi: 10.18632/oncotarget.1895.

87. Su X, Malouf GG, Chen Y, Zhang J, Yao H, Valero V, Weinstein JN, Spano J-P, Meric-Bernstam F, Khayat D, Esteva FJ. Comprehensive analysis of long non-coding RNAs in human breast cancer clinical subtypes. Oncotarget. 2014 Sep 8;5:9864-76. doi: 10.18632/oncotarget.2454.

88. Bhan A, Hussain I, Ansari KI, Kasiri S, Bashyal A, Mandal SS. Antisense-transcript long noncoding RNA (lncRNA) HOTAIR is transcriptionally induced by estradiol. J Mol Biol. 2013 Oct 9;425:3707-22.

89. Sun H, Wang G, Peng Y, Zeng Y, Zhu Q-N, Li T-L, Cai J-Q, Zhou H-H, Zhu Y-S. H19 lncRNA mediates 17-estradiol-induced cell proliferation in MCF-7 breast cancer cells. Oncol Rep. 2015 Apr 3;

90. Cronin M, Sangli C, Liu M-L, Pho M, Dutta D, Nguyen A, Jeong J, Wu J, Langone KC, Watson D. Analytical Validation of the Oncotype DX Genomic Diagnostic Test for Recurrence Prognosis and Therapeutic Response Prediction in Node-Negative, Estrogen Receptor-Positive Breast Cancer. Clin Chem. 2007 Jun 1;53:1084-91.

91. Brannon AR, Reddy A, Seiler M, Arreola A, Moore DT, Pruthi RS, Wallen EM, Nielsen ME, Liu H, Nathanson KL, Ljungberg B, Zhao H, Brooks JD, et al. Molecular Stratification of Clear Cell Renal Cell Carcinoma by Consensus Clustering Reveals Distinct Subtypes and Survival Patterns. Genes Cancer. 2010 Feb;1:152-63. doi: $10.1177 / 1947601909359929$.

92. The cancer genome atlas research network. Comprehensive molecular characterization of clear cell renal cell carcinoma. Nature. 2013 Jul 4;499:43-9.

93. Malouf GG, Zhang J, Yuan Y, Compérat E, Rouprêt M, Cussenot O, Chen Y, Thompson EJ, Tannir NM, Weinstein JN, Valero V, Khayat D, Spano J-P, et al. Characterization of long non-coding RNA transcriptome in clear-cell renal cell carcinoma by next-generation deep sequencing. Mol Oncol. 2015 Jan;9:32-43. doi: 10.1016/j. molonc.2014.07.007

94. Jiang Y, Malouf GG, Zhang J, Zheng X, Chen Y, Thompson EJ, Weinstein JN, Yuan Y, Spano JP, Broaddus R, Tannir NM, Khayat D, Lu KH, et al. Long non-coding RNA profiling links subgroup classification of endometrioid endometrial carcinomas with trithorax and polycomb complex aberrations. Oncotarget. 2015 Nov 24;6:39865-76. doi: 10.18632/oncotarget.5399.

95. Iyer MK, Niknafs YS, Malik R, Singhal U, Sahu A, Hosono Y, Barrette TR, Prensner JR, Evans JR, Zhao S, et 
al. The landscape of long noncoding RNAs in the human transcriptome. Nat Genet. 2015 Mar;47:199-208.

96. Holoch D, Moazed D. RNA-mediated epigenetic regulation of gene expression. Nat Rev Genet. 2015 Feb;16:71-84.

97. Tay Y, Rinn J, Pandolfi PP. The multilayered complexity of ceRNA crosstalk and competition. Nature. 2014 Jan 16;505:344-52.

98. Murthy VL, Rose GD. RNABase: an annotated database of RNA structures. Nucleic Acids Res. 2003 Jan 1;31:502-4.

99. Park C, Yu N, Choi I, Kim W, Lee S. IncRNAtor: a comprehensive resource for functional investigation of long non-coding RNAs. Bioinforma Oxf Engl. 2014 Sep 1;30:2480-5.

100. Chiu H-S, Llobet-Navas D, Yang X, Chung W-J, AmbesiImpiombato A, Iyer A, Kim HR, Seviour EG, Luo Z, Sehgal V, Moss T, Lu Y, Ram PT, et al. Cupid: simultaneous reconstruction of microRNA-target and ceRNA networks. Genome Res. 2014 Nov 5;gr.178194.114.

101. Chen Y, Zhu X, Zhang X, Liu B, Huang L. Nanoparticles Modified With Tumor-targeting scFv Deliver siRNA and miRNA for Cancer Therapy. Mol Ther. 2010 Sep;18:16506.
102. Svoboda M, Slyskova J, Schneiderova M, Makovicky P, Bielik L, Levy M, Lipska L, Hemmelova B, Kala Z, Protivankova M, Vycital O, Liska V, Schwarzova L, et al. HOTAIR long non-coding RNA is a negative prognostic factor not only in primary tumors, but also in the blood of colorectal cancer patients. Carcinogenesis. 2014 Jul;35:1510-5.

103. Xie H, Ma H, Zhou D, Xie H, Ma H, Zhou D. Plasma HULC as a Promising Novel Biomarker for the Detection of Hepatocellular Carcinoma, Plasma HULC as a Promising Novel Biomarker for the Detection of Hepatocellular Carcinoma. BioMed Res Int BioMed Res Int. 2013 May 22;2013, 2013:e136106.

104. Zhou X, Yin C, Dang Y, Ye F, Zhang G. Identification of the long non-coding RNA H19 in plasma as a novel biomarker for diagnosis of gastric cancer. Sci Rep. 2015 Jun 22;5:11516. doi: 10.1038/srep11516. 